\title{
Study of serum Vitamin D in Type II diabetes mellitus in Civil Hospital Ahmedabad
}

\author{
Anuja Adarsh', Vikas K Vaghela, ${ }^{2, *}$, Nayan mali ${ }^{3}$ \\ ${ }^{1,3}$ Resident, 2Senior Resident, ${ }^{1,2}$ Dept. of Biochemistry, ${ }^{3}$ Dept. of Physiology, ${ }^{1,3}$ B. J. Medical College, Ahmedabad, Gujarat, \\ ${ }^{2}$ AMC Medical College, Ahmedabad, Gujarat, India
}

*Corresponding Author:

Received: $21^{\text {st }}$ November, 2017

Email: Drvikaskvaghela@gmail.com

Accepted: $19^{\text {th }}$ December, 2017

\begin{abstract}
Introduction: Type-II diabetes is one of the most common non-communicable chronic disease and Vitamin D deficiency is also considered a public health problem around the world. As Vitamin D deficiency influence the insulin levels so this study is conducted.

Objectives: This study aims to evaluate serum level of Vitamin D in patients with type II diabetes mellitus.

Materials and Methods: 50 patients with type II diabetes is taken as cases and 50 healthy person taken as control. Study is conducted from june 2017 to sept. 2017 in Civil Hospital, Ahmedabad.

Result: In present study mean serum vitamin D level of case is significantly lower than controls. P value is $<0.05$

Conclusion: It suggests that alterations in vitamin D status may affect insulin sensitivity, $\beta$-cell function or both. So monitoring of Fasting plasma sugar \& Post prandial plasma sugar levels in patients along with serum Vitamin D plays an important role in prevention \& treatment of the Type II Diabetes Mellitus.
\end{abstract}

Keywords: Vitamin D, Diabetes Mellitus.

\section{Introduction}

Type-II diabetes is one of the most common noncommunicable chronic disease and its complications play a major role in morbidity and mortality worldwide. Diabetes is fastest growing with the status of a potential epidemic in India with more than 62 million diabetic individuals currently well diagnosed with the disease which is among the top 3 contributing nation followed by China and US. Vitamin D deficiency is also considered a public health problem around the world. Recent studies show that vitamin D deficiency may predispose to glucose intolerance, altered insulin secretion which leads to type -II diabetes mellitus. ${ }^{1}$

\section{Materials and Methods}

This study in Cross-sectional study conducted during june 2017 to September 2017 in Civil Hospital, Ahmedabad. 50 known patient of diabetes taken as cases and 50 apparently healthy individuals taken as controls.

Table 1: Diagnostic criteria for Diabetes Melitus Type II*

\begin{tabular}{|l|c|}
\hline \multicolumn{1}{|c|}{ Test } & Threshold \\
\hline HbA1c & $>6.5 \%$ \\
\hline FBS & $>126 \mathrm{mg} / \mathrm{dl}$ \\
\hline PPBS & $>200 \mathrm{mg} / \mathrm{dl}$ \\
\hline RBS & $>200 \mathrm{mg} / \mathrm{dl}$ \\
\hline $\begin{array}{l}\text { * NGSP- National Glycohemoglobin } \\
\text { standardization program }\end{array}$ \\
\hline
\end{tabular}

Inclusion Criteria: Comprised of diagnosed cases of Type II Diabetes Mellitus, both genders, aged 40-60 years.

Exclusion Criteria: Pediatric age group $(<18$ yrs), Pregnancy, Renal disorders, Hepatic disorders, Bone disorders, Hypertension or any other systemic illness that may affect plasma sugar \& Serum Vitamin D levels, Patients on any medications that might affects plasma sugar \& Serum Vitamin D levels.

Sample Collection: For serum vitamin D $5.0 \mathrm{ml}$ of blood collected with clot activator plain vaccute and samples are transported to the lab at $2-8^{\circ} \mathrm{C}$ immediately. Ensured the complete clot formation has taken place before to centrifugation in red/yellow vaccute. Some specimens, especially those from patients receiving anticoagulant or thrombolytic therapy, may show increased clotting time. Serum is removed from the clot within 2 hours of drawing the sample. For Plasma Glucose $5.0 \mathrm{ml}$ of blood is collected in fluoride vaccute and transported to the lab at $2-8^{\circ} \mathrm{C}$ immediately and centrifused. If testing was delayed for more than 24 hours, serum specimens are stored at $2-8^{\circ} \mathrm{C}$ and analyzed next day as per criteria (Ueland PM 1993). ${ }^{2}$

Sample Analysis: All samples are immediately analysed subjected to assays after thawing at $37^{\circ} \mathrm{C}$. The measurement of plasma glucose is analysed on an Erba XL 640 Fully Automated Analyzer by kit of crest biosystems, a division of coral clinical systems. The measurement of vitamnin D is analysed on Beckman \& coulter 600DXI.Serum Vitamin D level was estimated by Chemiluminescent Microparticle Immunoassay(CMIA) method. Fasting plasmasugar \& 
Post-prandial plasmasugar levels were estimated by GOD-POD method by colorimetry.

\section{Data Analysis}

Data was analyzed by unpaired $\mathrm{t}$ - test using graphpad prism version 3.03 statistical software which evaluated the differences of various parameters in both group cases and control on the basis of $\mathrm{p}$ value. Interpretation was done by $\mathrm{p}$-value $\{\mathrm{P}<0.05$ - Significant, $\mathrm{P}<0.001$ - Highly significant, $\mathrm{P} \geq 0.05$ - Not significant $\}$

\section{Result}

Table 2:

\begin{tabular}{|l|c|c|}
\hline \multicolumn{1}{|c|}{ Gender } & Cases & Controls \\
\hline Male & 26 & 27 \\
\hline Female & 24 & 23 \\
\hline Total & 100 & 50 \\
\hline
\end{tabular}

In present study there is equal distribution of gender so there is no bias.

Table 3:

\begin{tabular}{|l|c|c|c|c|c|}
\hline \multicolumn{1}{|c|}{ Test } & Cases & & Controls & & P value \\
\hline & Mean & SD & Mean & SD & \\
\hline FBS & 190.9 & 57 & 89.7 & 8.7 & $<0.05$ \\
\hline PPBS & 303.5 & 80.8 & 129.2 & 7.6 & $<0.05$ \\
\hline Vit D & 17.7 & 6.5 & 50.8 & 8.06 & $<0.05$ \\
\hline
\end{tabular}

The table shows that Serum Vitamin D is significantly lower in cases $(17.7 \pm 6.5) \mathrm{ng} / \mathrm{ml}$ as compared to controls $(50.8 \pm 7.8) \mathrm{ng} / \mathrm{ml} ; \mathrm{p}$ value $<0.05)$.

\section{Discussion}

In our study we found that vitamin d level is very low in cases as compare to controls which may be explained by this mechanism. Direct action via vitamin $\mathrm{D}$ receptor (VDR) activation which are present on $\beta$ cell of pancreas. Vitamin D influences $\beta$-cell insulin secretion by increasing intracellular calcium concentration via non selective voltage dependent calcium channels. Indirectly via calcemic hormones, $\beta$ cell calcium dependent endopeptidases, which produce the cleavage that facilitates the conversion of proinsulin to insulin.[3,4,5]Vitamin D have Immune-modulating properties therefore due to its deficiency Chronic lowgrade inflammation of pancreas is observed in obese individuals, which increases the risk of type 2 diabetes. ${ }^{6}$

\section{Conclusion}

Evidence from this study shows there is possible role of vitamin $\mathrm{D}$ in the pathogenesis of type 2 diabetes. It suggests that alterations in vitamin D status may affect insulin sensitivity, $\beta$-cell function or both. Thus, monitoring of Fasting plasma sugar \& Post prandial plasma sugar levels along with Vitamin D plays an important role in prevention \& treatment of the Type II Diabetes Mellitus.

\section{Limitations}

As our sample size is small here so confirmations by further study on large scale are necessary.

\section{References}

1. Mathieu C, Gysemans C, Guilietti A. Vitamin D and diabetes. Diabetologia 2005;48:1247-57.

2. Ueland PM, Refsum H, Stabler SP. Total homocysteine in plasma or serum: methods and clinical applications. Clin Chem 1993;39:1764-79.

3. Inomata $\mathrm{S}$, Kadowaki $\mathrm{S}$, Yamatani $\mathrm{T}$ et al. Effect of $1 \mathrm{a}(\mathrm{OH})$-vitamin $\mathrm{D} 3$ on insulin secretion in diabetes mellitus. Bone Miner 1986;1:187-92.

4. Ogunkolade BW, Boucher BJ, Prahl JM. Vitamin D receptor (VDR) mRNA and VDR protein levels in relation to vitamin D status, insulin secretory capacity, and VDR genotype in Bangladeshi Asians. Diabetes 2002;51:2294-300.

5. Holick MF. Vitamin D: importance in the prevention of cancers, type 1 diabetes, heart disease, and osteoporosis. Am J Clin Nutr 2004;79:362-71.

6. Zella JB, DeLuca HF. Vitamin D and autoimmune diabetes. J Cell Biochem 2003;88:216-22.

7. Zeitz U, Weber K, Soegiarto DW. Impaired insulin secretory capacity in mice lacking a functional vitamin D receptor. FASEB J 2003;17:509-11. 